\title{
Important differential diagnosis in acute tenosynovitis
}

\author{
Ian Franz Josef Pirker, Philipp Rein, Johannes von Kempis
}

Departement of Rheumatology, Immunology and Rehabilitation, Kantonsspital St. Gallen, St. Gallen, Switzerland

\section{Correspondence to Dr lan Franz Josef Pirker, ian.pirker@kssg.ch}

Accepted 21 December 2018

\section{DESCRIPTION}

We report the case of an 81-year-old male patient who was admitted to our hospital because of multiple cerebral ischaemic strokes. On day 2 of hospitalisation, he developed Pseudomonas aeruginosa sepsis, possibly secondary to a concomitant bladder infection. At day 3 of hospitalisation, tenderness of the right wrist with clinical signs of inflammation evolved. The peripheral intravenous access, localised distally of the radiocarpal joint, was initially suspected as the source of local infection (figure 1).

Subsequent ultrasound examination of the wrist showed signs of tenosynovitis of the extensor carpi ulnaris (ECU) tendon with tendon thickening and peritendinous effusion (figure 2), while the

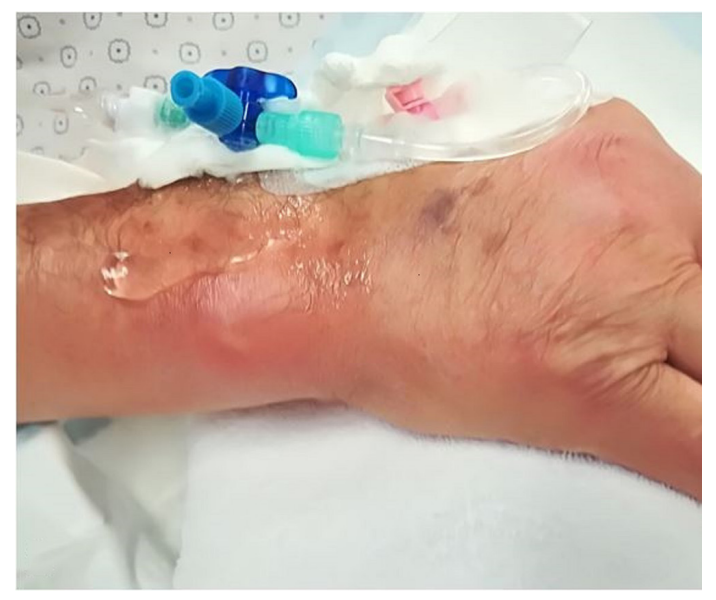

Figure 1 Right wrist: tenderness, hyperaemia and swelling of the ulnar part of the skin over the wrist.

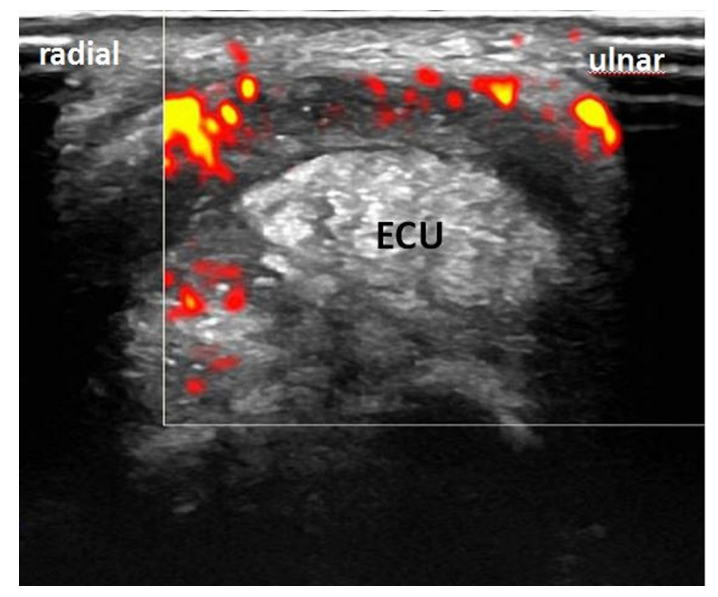

Figure 2 Transverse scan of the extensor carpi ulnaris (ECU): hyperaemia on colour Doppler, inhomogenous tendon thickening with hypoechogenic areas and surrounding halo sign.

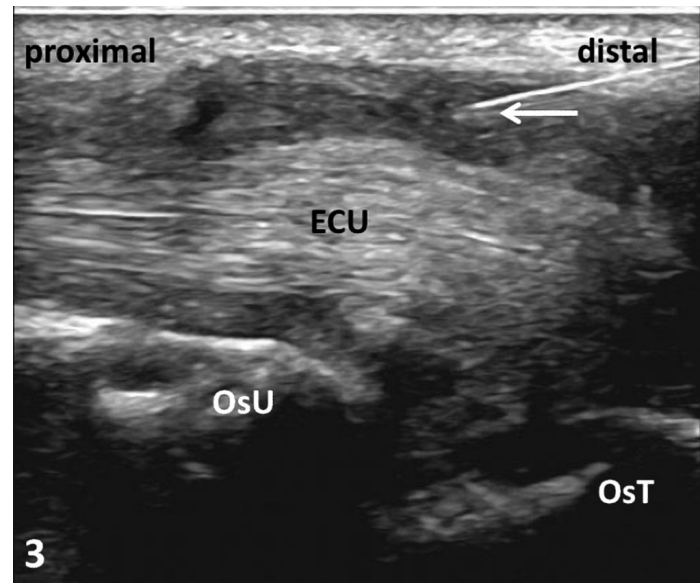

Figure 3 Longitudinal scan of the ECU: ultrasoundguided centesis of the tenosynovial sheath (arrow indicates the needle). ECU, extensor carpi ulnaris; OsT, os triquetrum; OsU, os ulnar head.

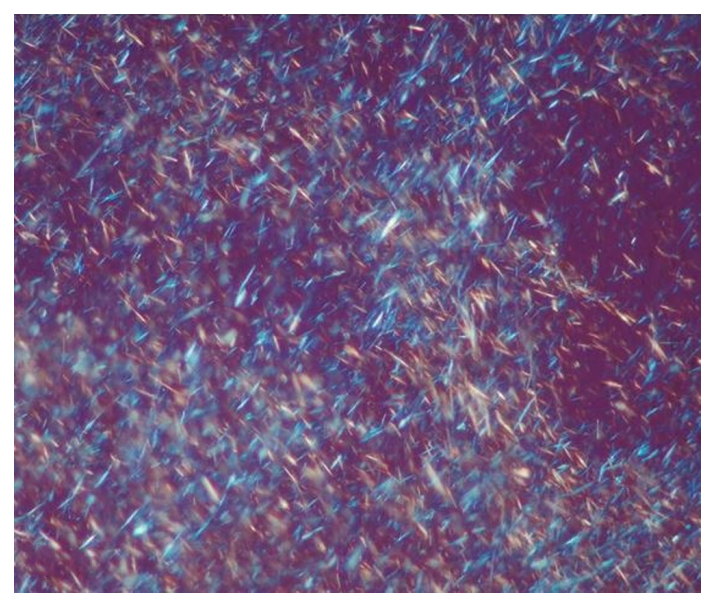

Figure 4 Polarised light microscopy of tenosynovial fluid (x100): strong negative birefringence, needle-shaped crystals identified as monosodium urate crystals.

radiocarpal joint revealed only grade 1 synovitis which did not explain the overall clinical appearance. ${ }^{1}$ In the absence of elevated serum urate levels, we suspected infectious tenosynovitis which might occur through haematogenous seeding or puncture wounds. ${ }^{2}$

Tenosynovial fluid drawn by ultrasound-guided puncture of the ECU sheath revealed monosodium urate crystals on polarised light microscopy, and a diagnosis of gouty tenosynovitis was established (figure 3 and figure 4). Injection with glucocorticosteroids into the tenosynovial sheath was performed and symptoms resolved after 3 days.

This clinical image demonstrates the diagnostic value of the examination of joints as well 
as tendons by ultrasound. Differential diagnosis of tenosynovitis of the wrist include rheumatoid arthritis, psoriatic arthritis, infectious tenosynovitis (may occur by haematogenous seeding or through puncture wounds) and calcium pyrophosphate dihydrate crystal deposition disease. ${ }^{2-5}$

Our example demonstrates that gout attacks can predominantly affect tendons, without major involvement of adjacent joints. In patients with infectious diseases and sonographic signs of tenosynovitis, centesis of the tenosynovial sheath and microscopic examination for crystals should be performed as gout flares can lead to tenosynovitis and mimic infectious tenosynovitis. $^{6}$

\section{Learning points}

- Gout attacks may manifest as tenosynovitis without involvement of adjacent joints.

- Centesis of the tenosynovial sheath and microscopic examination should be encouraged in acute tenosynovitis as gout flares may mimic infectious tenosynovitis.
Contributors IFJP was involved in treating the patient, performing of the intervention and in drafting and writing the manuscript. PR was involved in treating the patient and was a major contributor in writing the manuscript and critically revising the manuscript for important intellectual content. JvK was involved in treating the patient, critically revising for important intellectual content and has given final approval of the manuscript.

Funding The authors have not declared a specific grant for this research from any funding agency in the public, commercial or not-for-profit sectors.

Competing interests None declared.

Patient consent Next of kin consent obtained.

Provenance and peer review Not commissioned; externally peer reviewed.

\section{REFERENCES}

1 Gitto S, Draghi AG, Draghi F. Sonography of non-neoplastic disorders of the hand and wrist tendons. J Ultrasound Med 2018;37:51-68.

2 Draeger RW, Bynum DK. Flexor tendon sheath infections of the hand. J Am Acad Orthop Surg 2012;20:373-82.

3 Niemantsverdriet $E$, van der Helm-van Mil AHM. Imaging detected tenosynovitis of metacarpophalangeal and wrist joints: an increasingly recognised characteristic of rheumatoid arthritis. Clin Exp Rheumatol 2018;36:131-8.

4 Gutierrez M, Filippucci E, De Angelis R, et al. A sonographic spectrum of psoriatic arthritis: "the five targets". Clin Rheumatol 2010;29:133-42.

5 Yoshida H. Tenosynovitis due to pseudogout. N Z Med J 2016;129:84-5.

6 Weniger FG, Davison SP, Risin M, et al. Gouty flexor tenosynovitis of the digits: report of three cases. J Hand Surg Am 2003;28:669-72.

Copyright 2018 BMJ Publishing Group. All rights reserved. For permission to reuse any of this content visit https://www.bmj.com/company/products-services/rights-and-licensing/permissions/

BMJ Case Report Fellows may re-use this article for personal use and teaching without any further permission.

Become a Fellow of BMJ Case Reports today and you can:

- Submit as many cases as you like

- Enjoy fast sympathetic peer review and rapid publication of accepted articles

- Access all the published articles

- Re-use any of the published material for personal use and teaching without further permission

For information on Institutional Fellowships contact consortiasales@bmjgroup.com

Visit casereports.bmj.com for more articles like this and to become a Fellow 